\title{
Distribusi Nitrat dan Fosfat Secara Spasial dan Temporal Saat Musim Barat Di Permukaan Perairan Teluk Benoa, Bali
}

\author{
Ni Wayan Sukma Taraning Rahayu ${ }^{* *}$, I Gede Hendrawan ${ }^{a}$, Yulianto Suteja ${ }^{a}$ \\ a Program Studi Ilmu Kelautan, Fakultas Kelautan dan Perikanan, Universitas Udayana, Kampus UNUD Bukit Jimbaran, Bali 80361, Indonesia \\ *Penulis koresponden. Tel.: +6287-861-774-991 \\ Alamat e-mail: sukmataraning@gmail.com
}

Diterima (received) 22 Mei 2017; disetujui (accepted) 20 Agustus 2017; tersedia secara online (available online) 23 Agustus 2017

\begin{abstract}
Benoa Bay is an estuary that effected by pollutan from river and human activity. Reasearch on spatial and temporal distribution of nitrate and phosphate has been conducted in Benoa Bay. Data was collected at water surface during ebb from December 2016 to Februari 2017. There were19 Sampling pointlocated in Benoa Bay and 6 pointslocated in rivers around Benoa Bay. Nitrate was analysed using Brucine method and phosphate was analysed using AmmMolybdat method. The concentration of nitrate from December 2016 to February 2017 ranged from 0,036 mg/L to $1,154 \mathrm{mg} / \mathrm{L}$ and the concentration of phosphate ranged from undetectedto $0,739 \mathrm{mg} / \mathrm{L}$. The concentration of nitrate at rivers ranged from undetectedto 3,584 mg/L andthe concentration of phosphate ranged from undetectedto2,405 $\mathrm{mg} / \mathrm{L}$. The concentration of nitrate and phosphate from December 2016 to February 2017 was fluctuating and the highest average concentration of nitrat and phosphate was found in February 2017. These was due to high rainfall in February 2017 and cause a lot of organic matters carried by the rivers into Benoa Bay. The highest distribution concentration of nitrate and phosphate was found around estuary. These due to input of organic matters from mainland through the rivers. Based on water quality standards of Bali Goverment, the concentration of nitrate and phosphate was exceeds the seawater quality standart.
\end{abstract}

Keywords: Benoa Bay; Nitrate; Phosphate; Spatial distribution

\begin{abstract}
Abstrak
Teluk Benoa merupakan salah satu estuari yang mendapat masukan limbah dari sungai dan aktifitas manusia. Penelitian distribusi nitrat dan fosfat secara spasial dan temporal telah dilakukan di perairan Teluk Benoa. Pengambilan data dilakukan di permukaan air pada bulan Desember 2016 hingga Februari 2017 pada saat kondisi pasang menuju surut. Terdapat 19 titik di perairan Teluk Benoa dan di 6 titik muara sungai yang bermuara di Teluk Benoa. Metode untuk analisis nitrat yaitu dengan metode brusin, dan analisis fosfat dengan metode amm-molyddat. Konsentrasi nitrat dari bulan Desember 2016 hingga bulan Februari 2017 berkisar antara 0,036 mg/L hingga 1,154 $\mathrm{mg} / \mathrm{L}$ dan konsentrasi fosfat berkisar antara tidak terdeteksi hingga 0,739 mg/L. Konsentrasi nitrat di sungai yg bermuara di Teluk Benoa berkisar antara tidak terdeteksi hingga 3,584 mg/L dan konsentrasi fosfat berkisar antara tidak terdeteksi hingga2,405 mg/L.Konsentrasi nitrat dan fosfat dari bulan Desember 2016 hingga bulan Februari 2017 memiliki nilai yang fluktuatif dan rata-rata tertinggi pada bulan Februari 2017 yang diduga diakibatkan oleh kondisi curah hujan yang tinggi sehingga masukan unsur hara yang melalui aliran sungai menjadi tinggi. Sebaran konsentrasi nitrat dan fosfat tertinggi didominasi terdapat di sekitar muara sungai. Tingginya konsentrasi tersebut diduga diakibatkan oleh masukan bahan organik dari daratan melalui sungai ke Teluk Benoa. Berdasarkan Peraturan Gubernur Bali Nomor 16 Tahun 2016 tentang Baku Mutu Lingkungan Hidup dan Kriteria Baku Kerusakan Lingkungan Hidup, konsentrasi Nitrat dan Fosfat di semua titik pengambilan sampel pada setiap bulannya sudah melebihi baku mutu.
\end{abstract}

Kata Kunci: Teluk Benoa; Nitrat; Fosfat; Distribusi spasial 


\section{Pendahuluan}

Teluk Benoa merupakan salah satu estuari yang secara administratif terletak di Kabupaten Badung dan Kota Denpasar, Provinsi Bali dengan luas perairan teluk sekitar 1.998,1 Ha (Sudiarta dkk., 2013). Pada kawasan ini terdapat keanekaragaman ekosistem yaitu ekosistem mangrove, padang lamun, terumbu karang dan dataran pasang surut (Wiyanto dan Faiqoh, 2015; Faiqoh dkk., 2016; Karang, 2016). Teluk Benoa merupakan ekosistem estuari dangkal, dimana sejumlah sungai bermuara di perairan Teluk Benoa. Sungai yang bermuara di Teluk Benoa yaitu Sungai Badung, Sungai Mati, Sungai Sama, Sungai Bualu, Sungai Buaji dan Sungai Loloan (Risuana dkk., 2017).

Kualitas perairan Teluk Benoa sangat dipengaruhi oleh kondisi lingkungan perairan, salah satunya yaitu nitrat dan fosfat. Nitrat dan fosfat merupakan contoh nutrien yang dominan terdapat dalam suatu perairan yang digunakan oleh fitoplankton dan biota lainnya dalam proses rantai makanan (Simanjuntak, 2012). Akan tetapi jika konsentrasi nitrat dan fosfat memiliki konsentrasi yang sangat tinggi dan melebihi nilai baku mutu masuk ke perairan, maka akan menyebabkan eutrofikasi yaitu proses pengkayaan oleh zat hara di dalam suatu lingkungan perairan yang diindikasikan dengan terjadinya blooming fitoplankton (Simanjuntak, 2012).

Secara umum sumber utama nitrat dan fosfat yang masuk ke perairan adalah limbah yang berasal dari daratan berupa limbah industri dan pemukiman yang mengandung senyawa organik yang mengalir melalui sungai (Suteja, 2016), seperti yang diuraikan oleh Sari dkk. (2017) yang menyatakan bahwa terdapat Nitrat dan Fosfat di Sungai Loloan. Limbah tersebut mengalami penguraian menjadi senyawa anorganik dan masuk ke perairan (Rousseau et al., 2002). Selain itu di perairan Teluk Benoa terdapat berbagai kegiatan manusia seperti pariwisata, keramba jaring apung (KJA), pelabuhan yang berfungsi sebagai pelabuhan pariwisata dan pelabuhan perikanan (Dinas Peternakan, Perikanan dan Kelautan Kota Denpasar, 2014), serta dimanfaatkan untuk tempat pembuangan akhir sampah (TPA) yang terdapat di Desa Suwung Kauh, Kecamatan Denpasar Selatan (Ditjen Cipta Karya PU, 2003). Aktivitas inidapat mengakibatkan perubahan terhadap kandungan nitrat dan fosfat yang merupakan salah satu parameter untuk melihat kondisi perairan (Indra, 2002).
Keberadaan nitrat dan fosfat pada suatu perairan dipengaruhi oleh arus dan pasang surut (Hendrawan dan Ardana, 2009; Oktaviani et al., 2015). Konsentrasi nitrat dan fosfat pada saat kondisi surut memiliki nilai yang lebih tinggi dibandingkan dengan kondisi saat pasang. Hal ini disebabkan karena kondisi surut akan membawa massa air laut dari perairan dekat pantai menuju ke laut lepas, sehingga massa air laut berkurang dan limbah organik yang terbawa oleh aliran sungai akan menjadi lebih besar (Purwadi et al., 2016).

Kandungan nitrat dan fosfat di sekitar perairan Teluk Benoa melalui pengambilan sampel air laut secara langsung telah dilakukan oleh Dewanti (2016) yang menunjukkan konsentrasi nitrat berkisar 0,096-1,334 mg/l dan konsentrasi fosfat berkisar 0,003-0,223 $\mathrm{mg} / \mathrm{l}$. Akan tetapi pengambilan sampel air laut hanya dilakukan satu kali di sekitar perairan Teluk Benoa khususnya di sekitar perairan Pulau Serangan dan tidak memperhitungkan kondisi pasang surut. Selain itu, hasil dari penelitian yang dilakukan oleh Hendrawan dan Ardana (2009) mengenai fosfat di perairan Teluk Benoa dengan menggunakan metode modeling menunjukkan distribusi spasial konsentrasi fosfat melebihi $0,5 \mathrm{mg} / \mathrm{l}$ pada area muara sungai Badung, sungai Mati, TPA Suwung dan Pelabuhan Benoa.

Menurut Hendrawan dan Asai (2014) pertukaran massa air di dalam Teluk Benoa memerlukan waktu hampir satu bulan. Rendahnya pertukaran air laut tersebut berpengaruh terhadap waktu untuk pembilasan konsentrasi nitrat dan fosfat ke luar teluk. Adanya masukkan limbah secara terus menerus dan juga rendahnya pertukaran air laut akan mengakibatkan penumpukan konsentrasi nitrat dan fosfat di dalam teluk, dan akhirnya akan menurunkan kualitas perairan Teluk Benoa. Oleh karena itu diperlukan tindakan pencegahan agar tidak terjadi penurunan kualitas perairan.

Kegiatan pencegahan dapat dilakukan apabila area yang berpotensi sebagai sumber nitrat dan fosfat diketahui. Melalui kajian distribusi spasial, area yang berpotensi sebagai sumber nitrat dan fosfat dapat diketahui. Serta, melalui kajian distribusi secara temporal dapat memberikan informasi variabilitas konsentrasi nitrat dan fosfat. Mengingat pentingnya informasi kualitas perairan, khususnya kandungan nitrat dan fosfat, maka pada penelitian ini dilakukan kajian pola distribusi nitrat dan fosfat secara spasial dan temporal saat musim barat di perairan Teluk Benoa, Bali. 


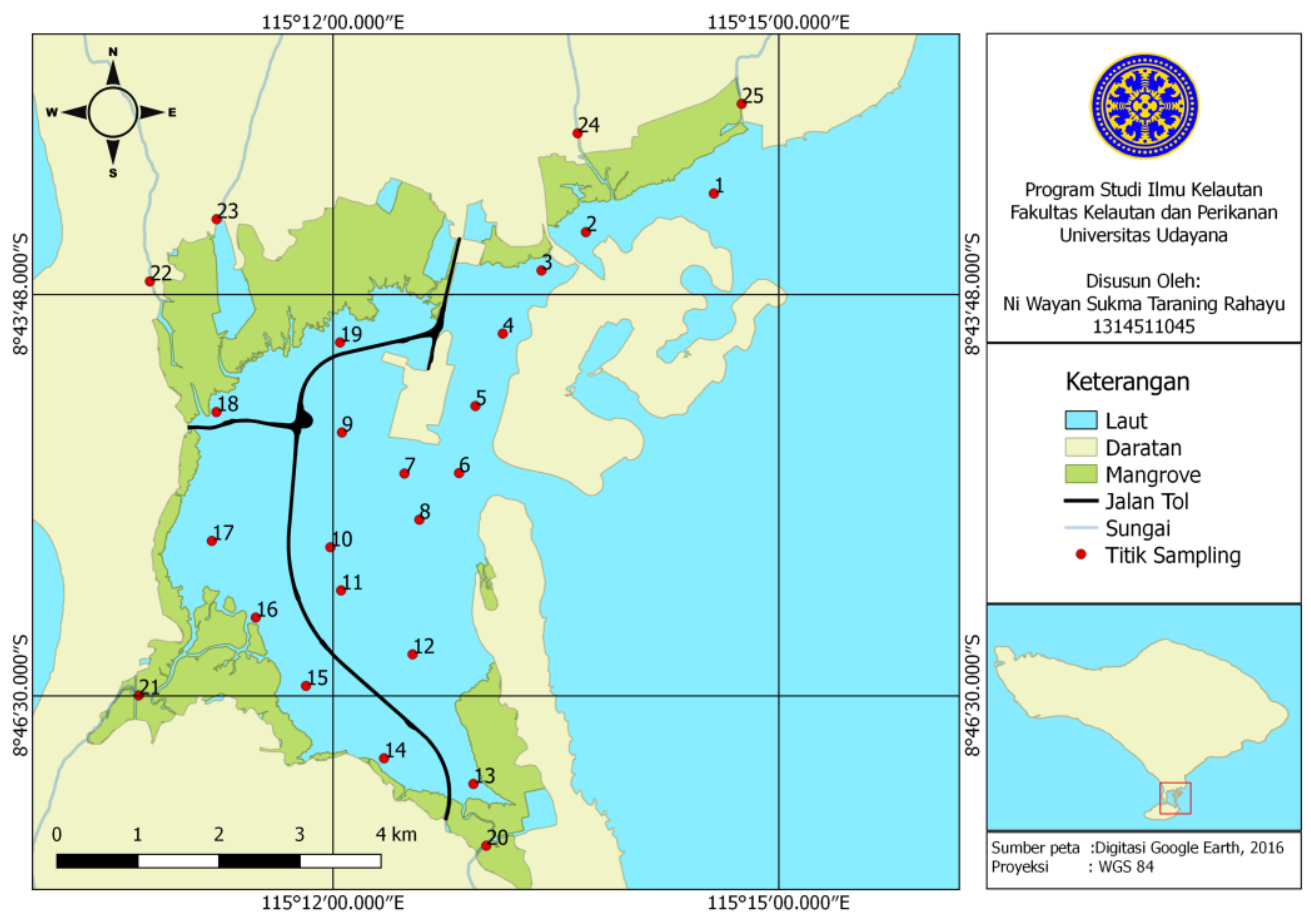

Gambar 1. Lokasi studi dan titik pengambilan sampel

\section{Metode Penelitian}

\subsection{Waktu dan Lokasi}

Penelitian ini dilaksanakan di perairan Teluk Benoa, Bali (Gambar 1). Pengambilan sampel nitrat dan fosfat dilakukan pada saat pasang purnama (spring tide) dengan kondisi pasang menuju surut. Pada penelitian ini pengambilan sampel dilakukan sebanyak tiga kali yaitu :

Periode Pertama : 12 Desember 2016, pukul

Periode Kedua : 11 Januari 2017, pukul 09.00-11.00 Wita

Periode Ketiga : 12 Februari 2017, pukul 11.10-13.30 Wita

Pengambilan sampel ini dilakukan untuk dapat mengetahui sebaran nitrat dan fosfat di dalam kawasan Teluk Benoa serta mengetahui puncak tingginya konsentrasi nitrat dan fosfat saat musim barat.

Penelitian ini dilakukan dalam dua bagian, yang terdiri dari pengambilan data lapangan dan analisis sampel air laut di laboratorium. Lokasi pengambilan sampel nitrat dan fosfat dipilih dengan menggunakan metode purposive sampling yang merupakan metode yang bertujuan untuk menentukan titik lokasi pengambilan sampel dengan tujuan yang sesuai pada penelitian
(Sugiyono, 2012). Dalam penelitian ini terdapat 25 titik penelitian, dimana 19 titik berada di dalam teluk dan 6 titik di sungai (Sungai Badung, Sungai Mati, Sungai Sama, Sungai Bualu, Sungai Buaji dan Sungai Loloan) yang bermuara ke Teluk Benoa (Gambar 1). Analisis laboratorium untuk menganalisa sampel air laut dilakukan di Laboratorium Kesehatan Provinsi Bali.

\subsection{Alat dan Bahan}

Alat dan bahan yang digunakan dalam penelitian ini disajikan pada Tabel 1. Seluruh alat dalam penelitian ini dikalibrasi sebelum digunakan untuk mengukur kualitas perairan.

Untuk data curah hujan harian diperoleh secara online dari website Badan Meteorologi dan Geofisika (BMKG) Stasiun Geofisika Klas II Sanglah Denpasardan Stasiun Meteorologi Ngurah Rai.

\subsection{Pengambilan Sampel}

Penentuan titik lokasi sampling dalam penelitian ini dilakukan dengan menggunakan GPS (Global Positioning System). Pengambilan sampel di dalam teluk dilakukan dengan menggunakan 2 kapal. Kapal 1 mengambil di titik 1, 2, 3, 4, 5, 6, 7, 8, 9 dan pada kapal 2 mengambil titik 10, 11, 12, 13, 14, 15, $16,17,18,19$. Pengambilan sampel air laut untuk analisis konsentrasi nitrat dan fosfat dilakukan di 


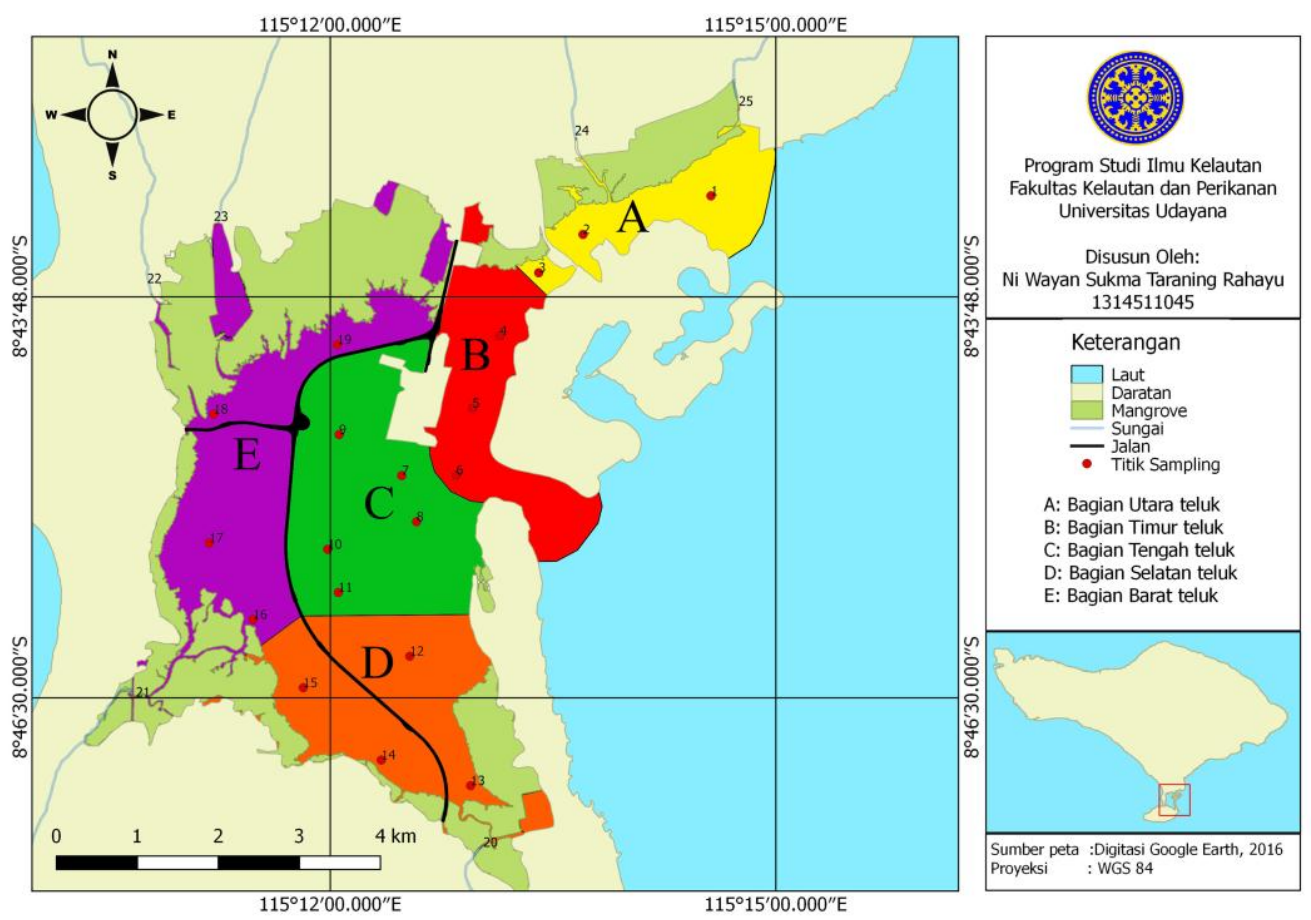

Gambar 2. Pembagian wilayah Teluk Benoa

permukaan perairan Teluk Benoa dengan menggunakan botol sampel dengan volume $600 \mathrm{ml}$ kemudian sampel dimasukkan kedalam cool box. Sampel air laut selanjutnya dianalisis di laboratorium Kesehatan Provinsi Bali.Selain nitrat dan fosfat dalam penelitian ini juga dilakukan pengukuran suhu, salinitas, dan derajat keasaman $(\mathrm{pH})$.

\subsection{Analisis Data}

\subsubsection{Analisis Konsentrasi Nitrat dan Fosfat}

Analisis konsentrasi nitrat dan fosfat dilakukan dengan metode Brusin (prosedur standar Departemen Kesehatan RI; Depkes RI, 2003) dan metode amm-molyddat (Standard Methods for the Examination of Water and Wastewater; Rice et al., 2012).

Setelah data konsentrasi nitrat dan fosfat diperoleh selanjutnya dilakukan perbandingan antara masing-masing titik pada setiap periode sampling. Konsentrasi nitrat dan fosfat kemudian di interpolasi dengan menggunakan metode interpolasi Inverse Distance Weighted (IDW) dan ditampilkan dalam bentuk peta pola sebaran, selain itu data juga ditampilkan dalam bentuk grafik batang pada bagian utara (titik 1,2,3), timur (titik 4,5,6), tengah (titik 7,8,9,10,11), selatan (titik $12,13,14,15)$, dan barat $(16,17,18,19)$ Teluk Benoa selama tiga bulan penelian (Gambar 2).
Tabel 1

Alat dan bahan penelitian

\begin{tabular}{lcl}
\hline \multicolumn{1}{c}{ Jenis } & Spesifikasi & \multicolumn{1}{c}{ Kegunaan } \\
\hline Botol Sampel & $600 \mathrm{ml}$ & Tempat sampel air \\
GPS & GPSMAP 78s & $\begin{array}{l}\text { Penentuan titik lokasi } \\
\text { penelitian }\end{array}$ \\
Cool Box & & Menyimpan sampel \\
Label & Memberikan keterangan \\
& pada botol sampel \\
Aquades & Membersihkan alat-alat \\
& & pengukuran sampel \\
Tissue & Untuk mengeringkan alat \\
\hline
\end{tabular}

\subsubsection{Analisis Konsentrasi Distribusi Spasial}

Distribusi spasial nitrat dan fosfat serta suhu, salinitas, dan derajat keasaman $(\mathrm{pH})$ di lakukan dengan metode interpolasi Inverse Distance Weighted (IDW). Kelebihan dengan menggunakan metode IDW yaitu hasil interpolasi dapat di tentukan dengan membatasi titik-titik yang digunakan dalam penelitian (Pramono, 2008). Pada saat proses interpolasi nitrat dan fosfat, nilai yang tidak terdeteksi dibiarkan kosong.

Pada interpolasi dengan metode IDW terdapat nilai power yang berfungsi menentukan pengaruh 
terhadap titik titik input. Pembobotan pada metode IDW merupakan inverse dari fungsi kuadrat jarak yang dirumuskan dengan formula berikut (Azpurua and Ramos, 2010):

$$
\mathrm{Z}^{*}=\sum_{i-1}^{\mathrm{N}} \omega_{i} \mathrm{Z}_{i}
$$

Dimana $Z i(I=1,2,3, \ldots N)$ merupakan nilai ketinggian data yang akan diinterpolasi oleh sejumlah $N$ titik. Sedangkan bobot $\omega i$ dirumuskan dengan formula berikut :

$$
\omega_{i}=\frac{h_{i}^{-p}}{\sum_{j=0}^{n} h_{j}^{-p}}
$$

Dimana $p$ adalah merupakan parameter yang nilainya bisa berubah ubah yang disebut power dan $h j$ adalah jarak sebaran dari titik ke titik interpolasi yang dirumuskan melalui formula berikut :

$$
h_{i}=\sqrt{\left(x-x_{i}\right)^{2}+\left(y-y_{i}\right)^{2}}
$$

Dimana $(x, y)$ merupakan koordinat interpolasi sedangkan $(x i, y i)$ merupakan koordinat sebaran semua titik.

\section{Hasil dan Pembahasan}

\subsection{Curah Hujan}

Data curah hujandi perairan Teluk Benoa selama tiga bulan penelitian ditampilan agar dapat melakukan analisis lebih mendalam (Gambar 3). Curah hujan dapat meningkatkan kandungan unsur hara nitrat dan fosfat di perairan. Hal ini disebabkan karena tingginya curah hujan akan menyebabkan pasokan air yang masuk ke perairan laut meningkat melalui aliran sungai yang membawa unsur hara nitrat dan fosfat (Tuahatu dan Tubalawony, 2008). Berdasarkan data curah hujan yang diperoleh dari Badan Meteorologi dan Geofisika (BMKG) Stasiun Geofisika Klas II Sanglah Denpasar dan Stasiun Meteorologi Ngurah Raipada bulan Desember 2016 memiliki rata-rata curah hujan harian sebesar 13,5 mm/hari, pengambilan sampel pada periode pertamadilakukan saat kondisi cuaca mendung dan dua hari sebelumnya terjadi hujan secara berturut-turut. Pada bulan Januari 2017 memiliki rata-rata curah hujan harian sebesar 10,4 mm/hari, pengambilan sampel pada periode kedua dilakukan saat kondisi cuaca berawan dan satu hari sebelumnya cuaca cerah. Pada pengambilan sampel periode ketiga tanggal 12 Februari 2017 dilakukan saat kondisi curah hujan 19,95 mm. Secara Keseluruhan terlihat pada Gambar 3, bahwa terjadi fluktuasi jumlah curah hujan dari bulan Desember 2016 hingga Februari 2017. Pada bulan Januari 2016 mengalami penurunan jumlah curah hujan tetapi kemudian meningkat pada bulan Februari 2017 dengan rata-rata 14,42 $\mathrm{mm} /$ hari, hal ini menunjukkan bahwa musim barat (hujan) mengalami puncaknya pada bulan Februari 2017.

\subsection{KonsentrasiNitrat}

Berdasarkan hasil analisis nilai konsentrasi nitrat yang telah dilakukan di sungai yang bermuara di perairan Teluk Benoa pada saat pasang menuju surut diperoleh nilai konsentrasi nitrat terendah sebesar 0,406 mg/L terdapat pada Sungai Mati di bulan Januari 2017 dan tertinggi sebesar 3,584 $\mathrm{mg} / \mathrm{L}$ terdapat pada Sungai Badung di bulan Februari 2017. Tingginya konsentrasi nitrat pada Sungai Badung karena merupakan salah satu sungai yang mengalir dan memasuki Kota

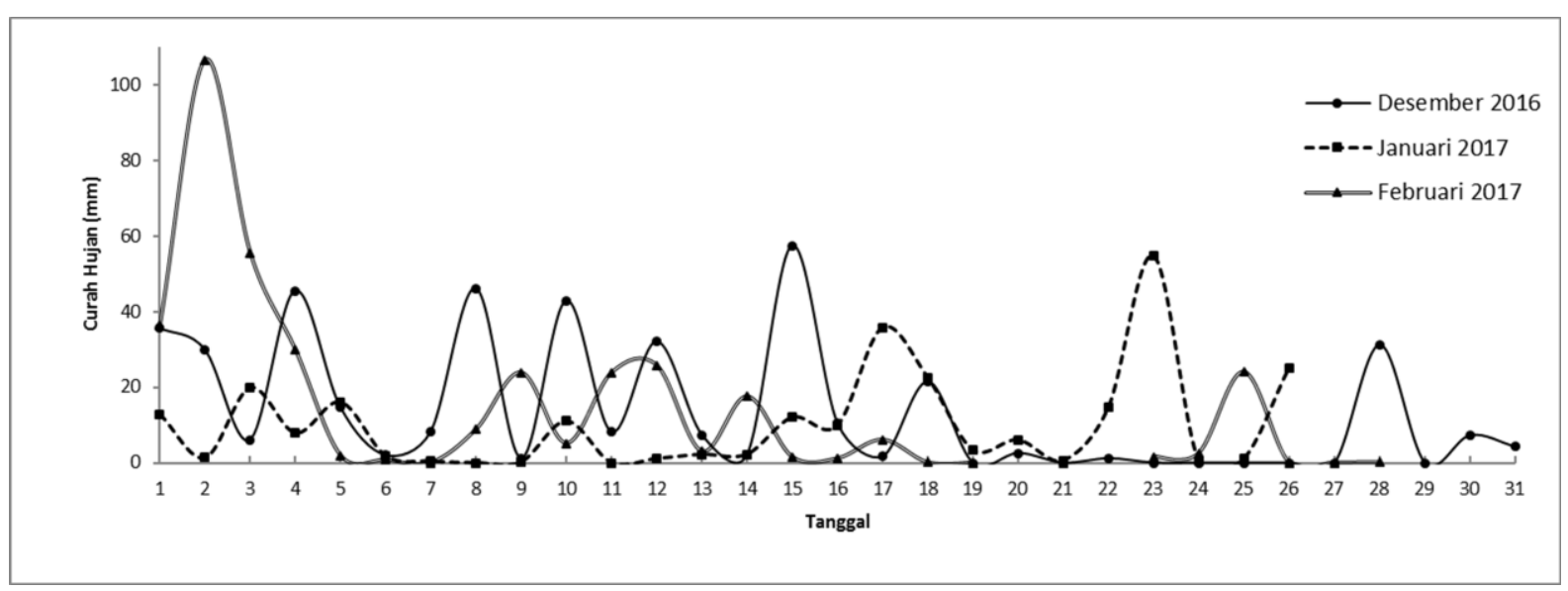

Gambar 3. Curah hujan bulan Desember 2016, Januari 2017, Februari 2017 


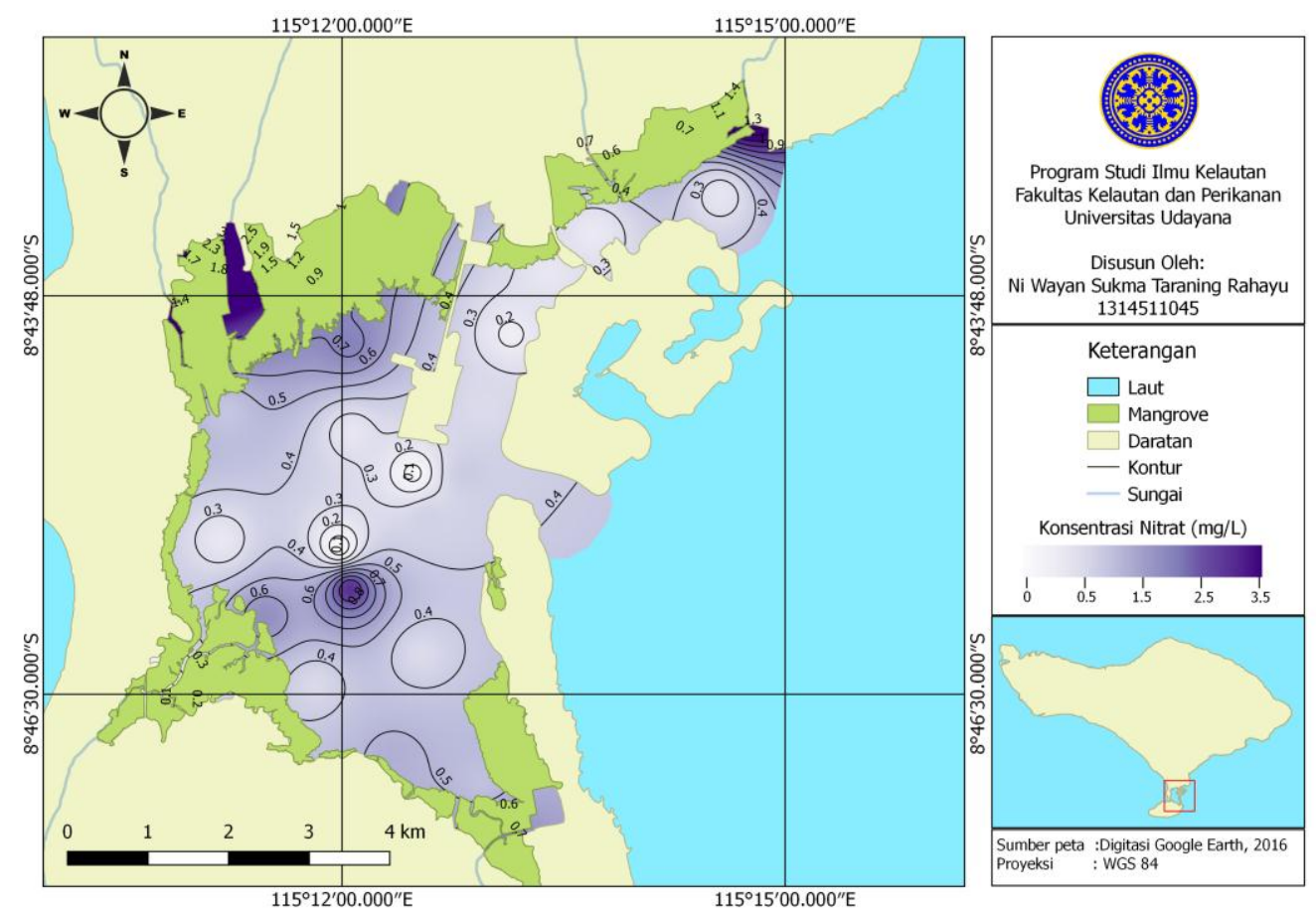

Gambar 4. Distribusi spasial nitrat di permukaan perairan Teluk Benoa bulan Desember 2016

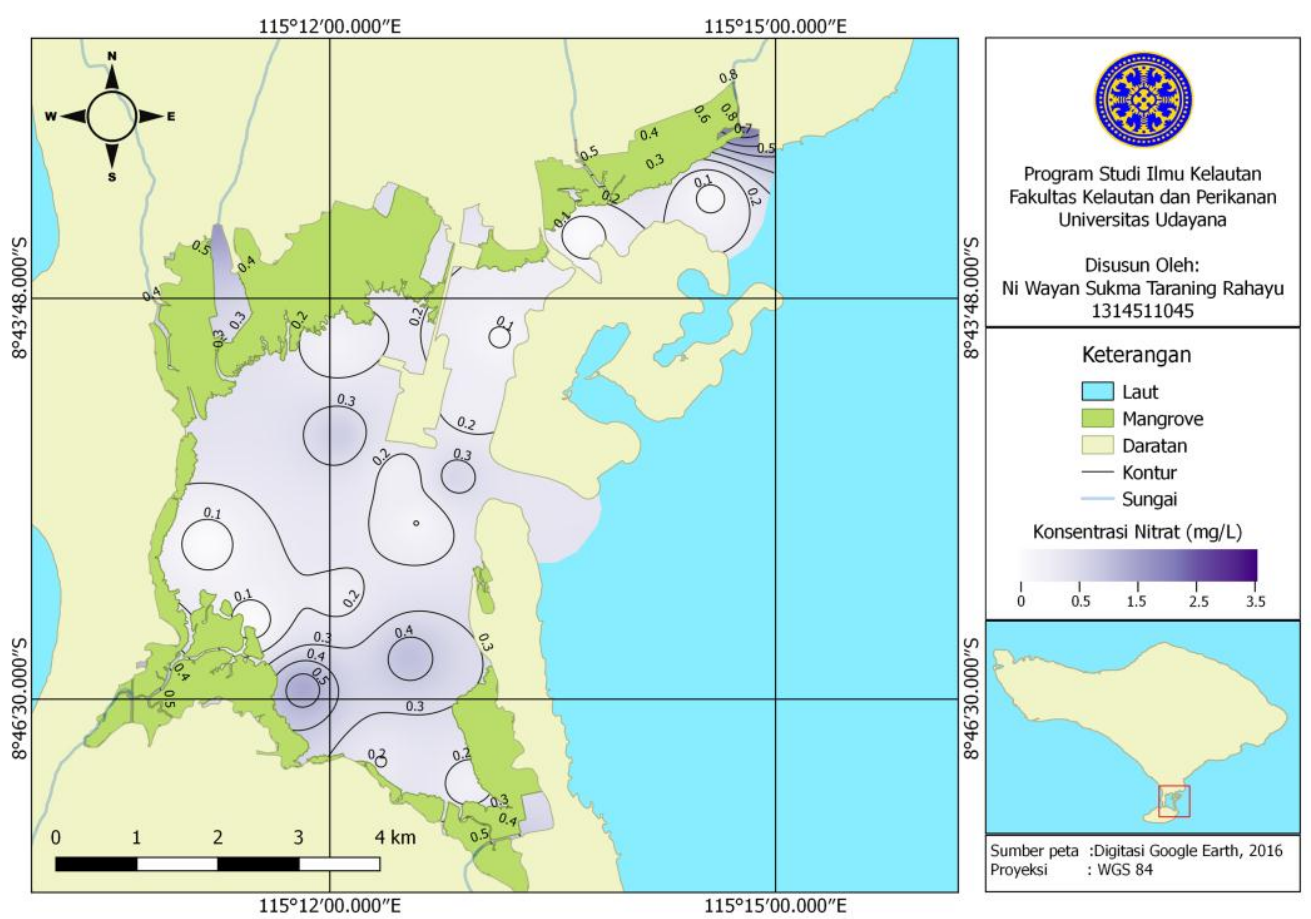

Gambar 5. Distribusi spasial nitrat di permukaan perairan Teluk Benoa bulan Januari 2017

Denpasar setelah mengalir dari wilayah Kabupaten Badung yang mendapat tekanan berbagai aktivitas seperti pemukiman penduduk, pertanian (hulu), peternakan, bengkel, laundry, pasar, rumah sakit, industri pangan dan kerajinan serta perkantoran (Mahendra et al., 2015) aktivitas tersebut dapat meningkatkan kandungan nitrat. Konsentrasi nitrat yang rendah pada Sungai Mati diduga karena panjang aliran Sungai Mati lebih pendek yaitu 12,25 km daripada Sungai Badung dengan panjang 17,15 km (BPS, 2015) sehingga beban masukan limbah yang mengandung unsur hara nitrat lebih rendah. Pada perairan laut diperoleh nilai konsentrasi nitrat terendah sebesar 0,036 mg/L terdapat pada bagian tengah teluk (titik 10) di bulan Januari 2017 dan tertinggi 
sebesar 1,154 mg/L terdapat pada bagian barat teluk (titik 18) di bulan Februari.

Hasil analisis konsentrasi nitrat pada bulan Desember 2016 di perairan laut rata-rata nilai konsentrasi nitrat sebesar $0,367 \mathrm{mg} / \mathrm{L}$ dengan nilai terendah sebesar $0,036 \mathrm{mg} / \mathrm{L}$ terdapat padabagian tengah teluk (titik 10) dan tertinggi 0,996 mg/L pada bagian tengah teluk (titik 11). Tingginya konsentrasi nitrat di titik 11 diduga dipengaruhi oleh masukan limbah dari daratan yang mengandung bahan anorganik yang dialirkan melalui sungai ke perairan laut. Senyawa anorganik ini mengandung zat hara nitrat, sedangkan konsentrasi nitrat di sungai berkisar antara 0,721-3,333 $\mathrm{mg} / \mathrm{L}$ dengan rata-rata sebesar $1,554 \mathrm{mg} / \mathrm{L}$. Konsentrasi nitrat terendah terdapat di Sungai Buaji dan tertinggi di Sungai Badung. Hal ini menunjukkan bahwa Sungai Badung memiliki pengaruh yang besar terhadap kandungan nitrat di perairan Teluk Benoa, terlihat pada titik 19 di sekitar muara Sungai Badung pada bagian barat teluk memiliki nilai konsentrasi nitrat yang tinggi sebesar 0,726 mg/L.

Distribusi spasial konsentrasi nitrat di permukaan perairan Teluk Benoa pada bulan Desember 2016 yang disajikan pada Gambar 4, menunjukkan adanya peningkatan di daerah muara Sungai Loloan, Sungai Badung, Sungai Mati dan Sungai Sama. Konsentrasi nitrat cenderung memiliki nilai yang lebih rendah pada bagian tengah hingga timur teluk dibandingkan dengan bagian teluk yang lain. Hal ini mengindikasikan bahwa terdapat proses yang kompleks baik fisika maupun biologi seperti arus dan tingkat pemanfaatan nitrat sehingga mengakibatkan variasi kandungan nitrat.

Pada bulan Januari 2017 diperoleh konsentrasi nitrat di perairan laut Teluk Benoa berkisar antara 0,045-0,555 mg/L dengan rata-rata sebesar 0,196 $\mathrm{mg} / \mathrm{L}$. Konsentrasi nitrat terendah terdapat pada bagian barat teluk (titik 17) dan nilai tertinggi terdapat pada bagian selatan teluk (titik 15). Tingginya konsentrasi nitrat di titik 15 diduga karena posisinya yang terletak di dekat muara Sungai Sama yang mendapat pengaruh masukan zat organik dari daratan melalui sungai. Sedangkan konsentrasi nitrat di sungai berkisar antara 0,406 - 0,877 $\mathrm{mg} / \mathrm{L}$ dengan rata-rata sebesar 0,605 mg/L (Gambar 5). Berbeda dengan bulan Desember 2016, konsentrasi nitrat terendah pada bulan Januari 2017 terdapat di Sungai Mati dan tertinggi terdapat di Sungai Loloan. Secara keseluruhan distribusi spasial nitrat pada bulan Januari 2017 menunjukkan nilai konsentrasi terendah selama tiga bulan penelitian. Hal ini diduga disebabkan oleh rendahnya curah hujan pada bulan Januari 2017 sehingga masukan nitrat melalui sungai ke perairan Teluk Benoa rendah, terlihat bahwa rata-rata nilai konsentrasi nitrat di sungai yang rendah sebesar $0,605 \mathrm{mg} / \mathrm{L}$ sedangkan pada bulan Desember 2016 dan Februari 2017 masing-masing memiliki nilai sebesar $1,554 \mathrm{mg} / \mathrm{L}$ dan $1,591 \mathrm{mg} / \mathrm{L}$. Selain itu diduga pada saat

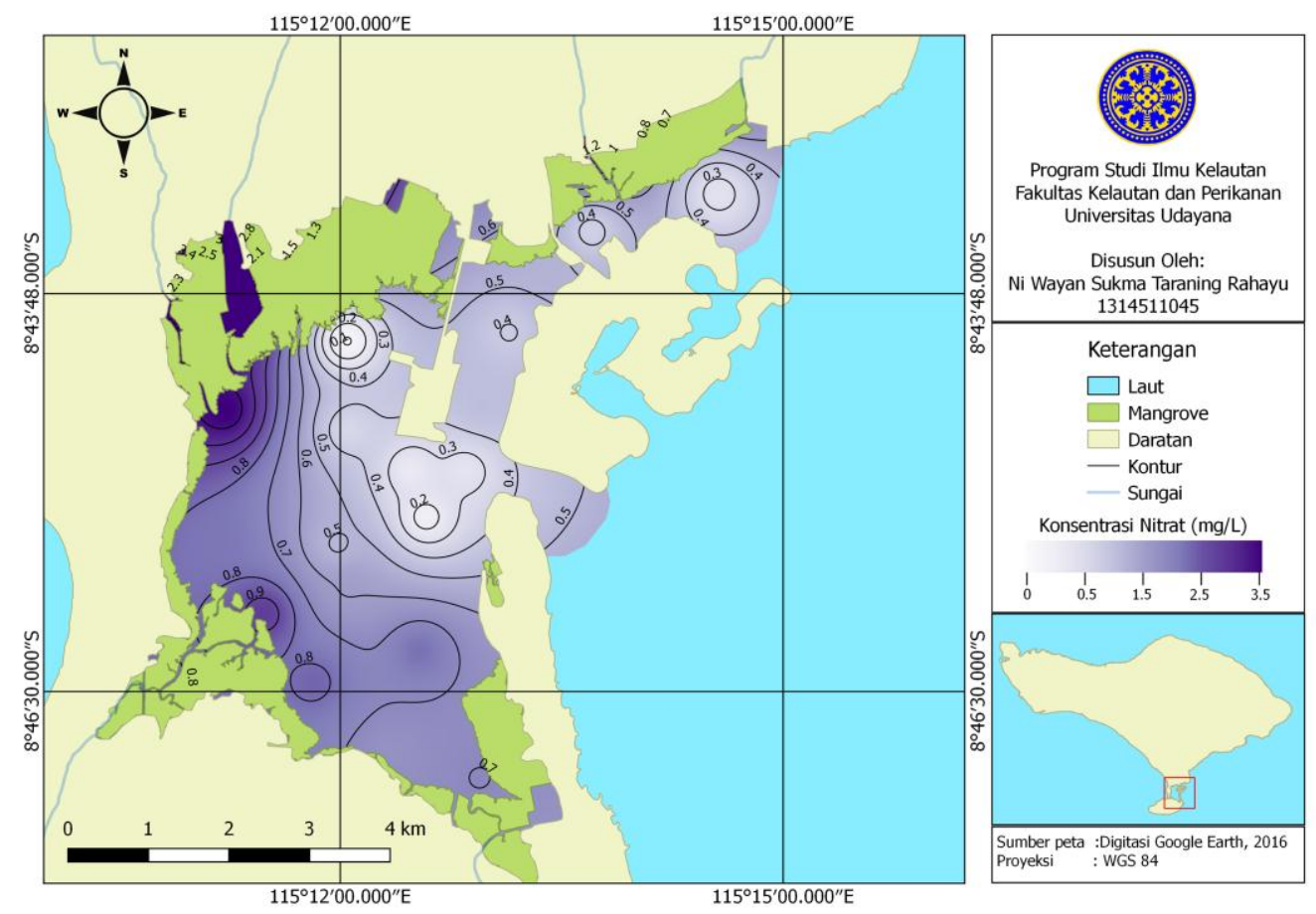

Gambar 6. Distribusi spasial nitrat di permukaan perairan Teluk Benoa bulan Februari 2017 
pengambilan sampel kondisi perairan masih didominasi oleh massa air dari luar Teluk Benoa yang dilihat dari pengukuran nilai salinitas yang tinggi pada bulan ini. Massa air dari luar teluk memiliki konsentrasi nitrat yang rendah. Pada umumnya nilai konsentrasi nitrat di perairan tidak melebihi 0,1 mg/L (Effendi, 2003).

Nilai konsentrasi nitrat pada Bulan Februari 2017 disajikan pada Gambar 6. Nilai konsentrasi nitrat terendah di sungai sebesar $0,623 \mathrm{mg} / \mathrm{L}$ terdapat pada Sungai Bualu dan tertinggi sebesar 3,584 mg/L terdapat pada Sungai Badung dengan nilai rata-rata sebesar $1,591 \mathrm{mg} / \mathrm{L}$ sedangkan di perairan laut rata-rata nilai konsentrasi nitrat sebesar $0,526 \mathrm{mg} / \mathrm{L}$ dengan nilai terendah sebesar $0,094 \mathrm{mg} / \mathrm{L}$ terdapat pada bagian barat teluk (titik 19) dan nilai tertinggi sebesar $1,154 \mathrm{mg} / \mathrm{L} \mathrm{di}$ terdapat pada bagian barat teluk (titik 18). Tingginya kandungan nitrat di titik 18 diduga karena posisinya terletak di dekat muara Sungai Mati dan Sungai Badung yang masing-masing memiliki nilai konsentrasi nitrat yang tinggi. Nutrien di perairan laut pada umumnya bersumber dari kawasan estuari dengan konsentrasi nutrien lebih tinggi di daerah muara dan lebih rendah menuju ke arah laut lepas (Muchtar, 2001).

Nilai rata-rata konsentrasi nitrat dari bulan Desember 2016 hingga Februari 2017 menunjukkan nilai terendah hingga tertinggi berturut yaitu bulan Januari 2017, Desember 2016 dan Februari 2017. Konsentrasi nitrat yang tinggi pada bulan Februari 2017 dikarenakan tingginya curah hujan pada bulan ini yaitu 22,02 $\mathrm{mm}$ /hari berbeda dengan bulan Januari 2017 yang disebabkan oleh curah hujan yang rendah yaitu 11,42 mm/hari. Pada bulan Februari 2017 nilai konsentrasi nitrat tertinggi terdapat pada bagian selatan dan barat teluk dan cenderung homogen pada bagian utara, timur dan tengah teluk. Pada bulan Januari 2017 memiliki nilai konsentrasi nitrat terendah pada seluruh bagian teluk. Pada bagian barat teluk menunjukkan nilai konsentrasi nitrat yang berfluktuasi signifikan selama tiga bulan penelitian dibandingkan bagian teluk lainnya. Secara umum tinggi pada bagian selatan dan barat teluk diduga karena pada daerah tersebut kurang dipengaruhi oleh massa air dari luar teluk pada saat kondisi pasang menuju surut yang dapat dilihat dari pengukuran nilai salinitas yang cenderung menurun pada bagian teluk tersebut (Gambar 7).

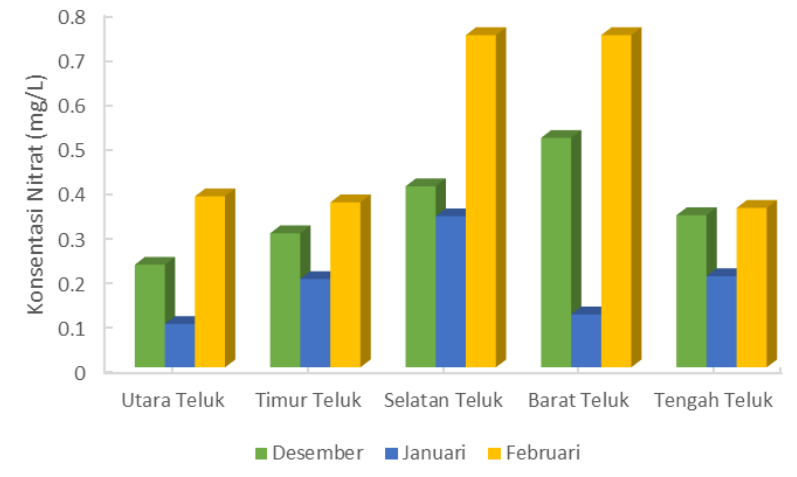

Gambar 7. Konsentrasi Nitrat bulan Desember 2016 hingga Februari 2017

Secara keseluruhan rata-rata konsentrasi nitrat selama tiga bulan penelitian cukup tinggi berkisar antara tidak terdeteksi hingga $3,584 \mathrm{mg} / \mathrm{L}$, dibandingkan dengan nilai yang diperoleh Oktaviani et al., 2015 yaitu 0,3076-0,6145 mg/L maupun Karil et al., 2015 yaitu 0,4291-0,7935 mg/L. Nilai yang diperoleh oleh Oktaviani et al., 2015 pada Muara Sungai Banjir Kanal Barat, Semarang maupun Karil et al., 2015 di Perairan Teluk Ujungbatu Jepara sumber pencemarannya lebih rendah dibandingkan dengan yang ada di Teluk Benoa yang memiliki 6 sungai sebagai penyumbang limbah dari daratan. Berdasarkan Pemprov Bali (2016) terkait dengan Baku Mutu Lingkungan Hidup dan Kriteria Baku Kerusakan Lingkungan Hidup, konsentrasi nitrat di semua titik pengambilan pada setiap bulannya sudah melebihi baku mutuuntuk wisata bahari dan biota laut 0,008 mg/L (Gambar 8).

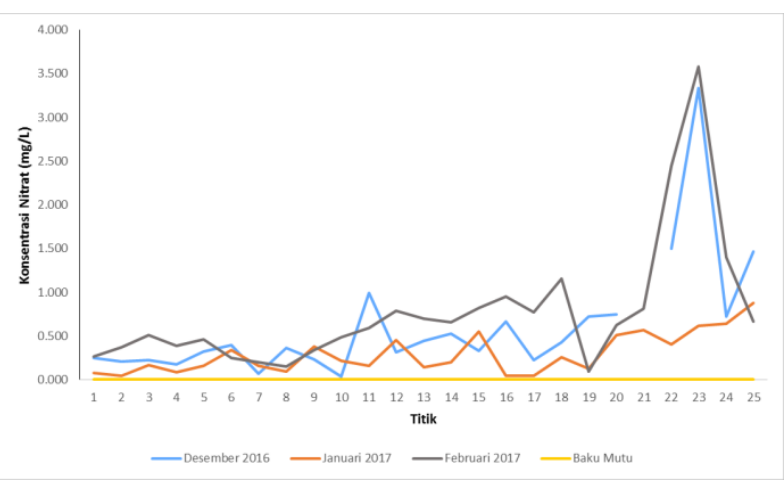

Gambar 8. Baku mutu konsentrasi nitrat

\subsection{Konsentrasi Fosfat}

Berdasarkan hasil pengamatan terhadap konsentrasi fosfat yang telah dilakukan di sungai yang bermuara di perairan Teluk Benoa pada saat pasang menuju surut selama 3 Bulan, diperoleh nilai konsentrasi fosfat terendah sebesar 0,043 


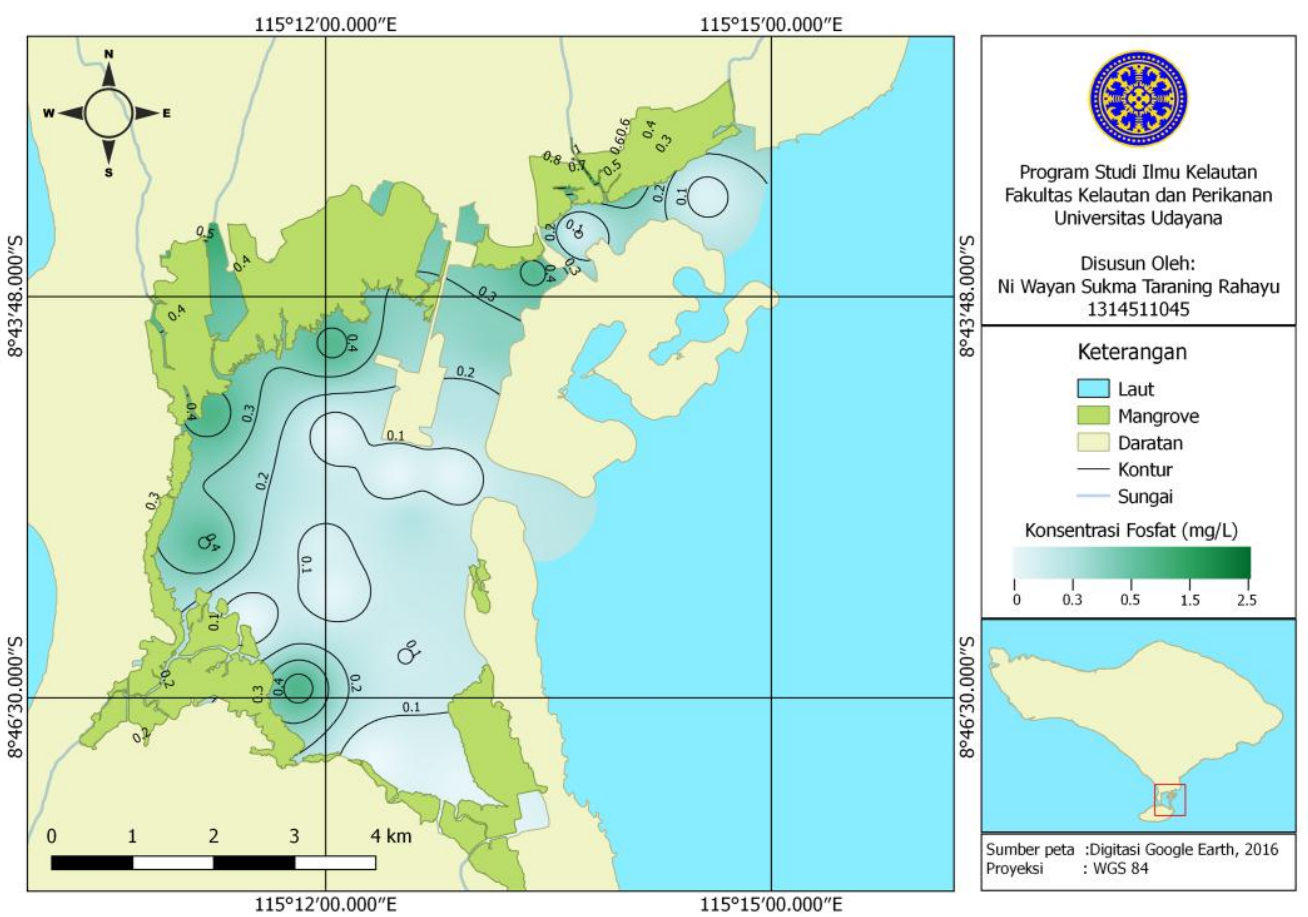

Gambar 9. Distribusi spasial fosfat di permukaan perairan Teluk Benoa bulan Desember 2016

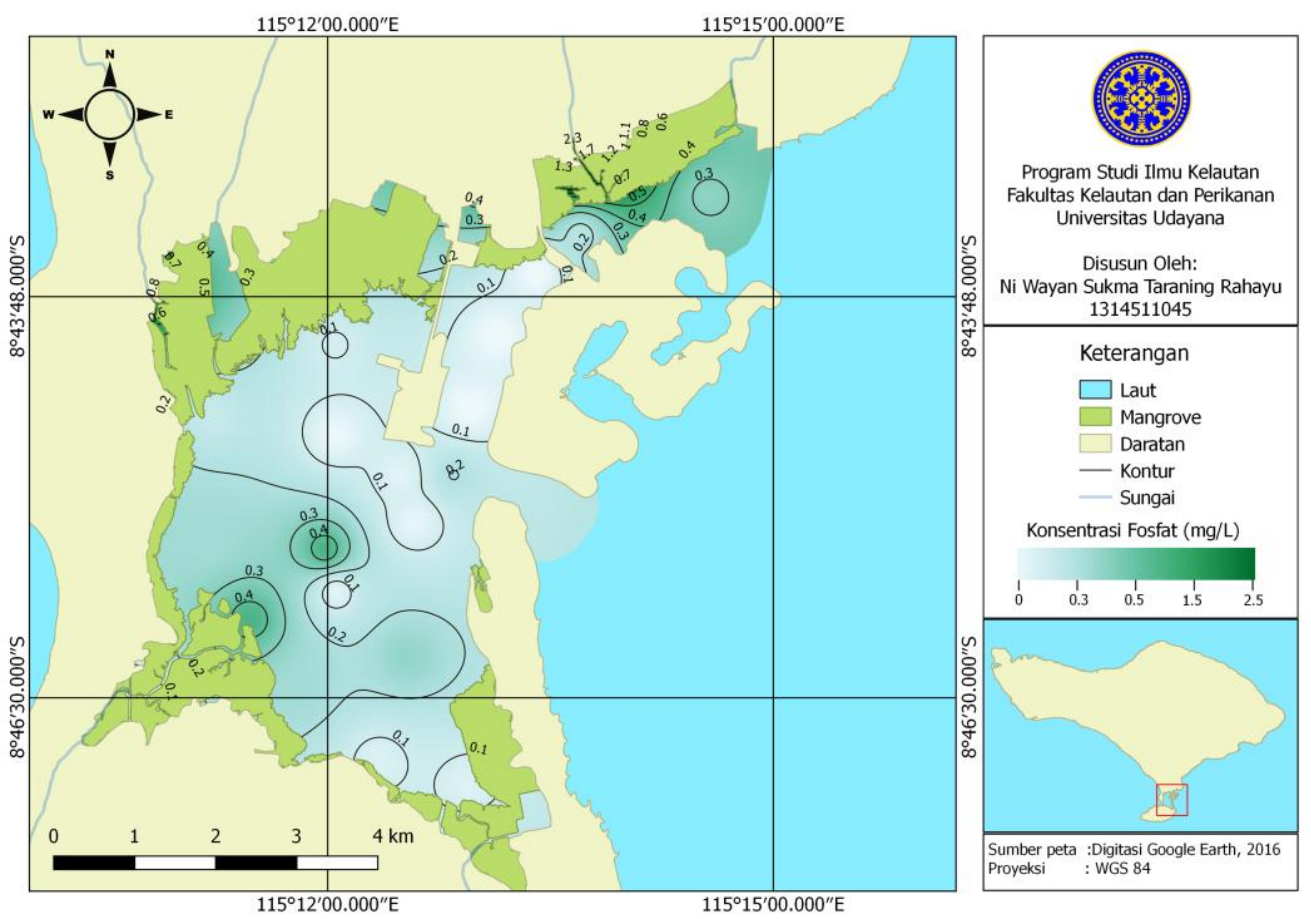

Gambar 10. Distribusi spasial fosfat di permukaan perairan Teluk Benoa bulan Januari 2017

$\mathrm{mg} / \mathrm{L}$ terdapat pada Sungai Sama di bulan Januari dan tertinggi sebesar 2,405 mg/L terdapat pada Sungai Buaji pada bulan Februari. Nilai konsentrasi fosfat di perairan berkisar 0,016-0,739 $\mathrm{mg} / \mathrm{L}$. Rata-rata nilai kandungan fosfat pada bulan Desember dan Januari sebesar $0,175 \mathrm{mg} / \mathrm{L}$ dan pada bulan Februari sebesar 0,198 mg/L. Analisis nilai konsentrasi fosfat di perairan laut setiap bulannya diperoleh hasil pada bulan Desember 2016 nilai konsentrasi fosfat terendah sebesar 0,018 $\mathrm{mg} / \mathrm{L}$ terdapat pada bagian selatan teluk (titik 14) dan tertinggi sebesar $0,444 \mathrm{mg} / \mathrm{L}$ terdapat pada bagian barat teluk (titik 18 ).

Tingginya konsentrasi fosfat di titik 18 diduga karena terletak di dekat muara Sungai Mati. Sungai merupakan salah satu perantara yang 


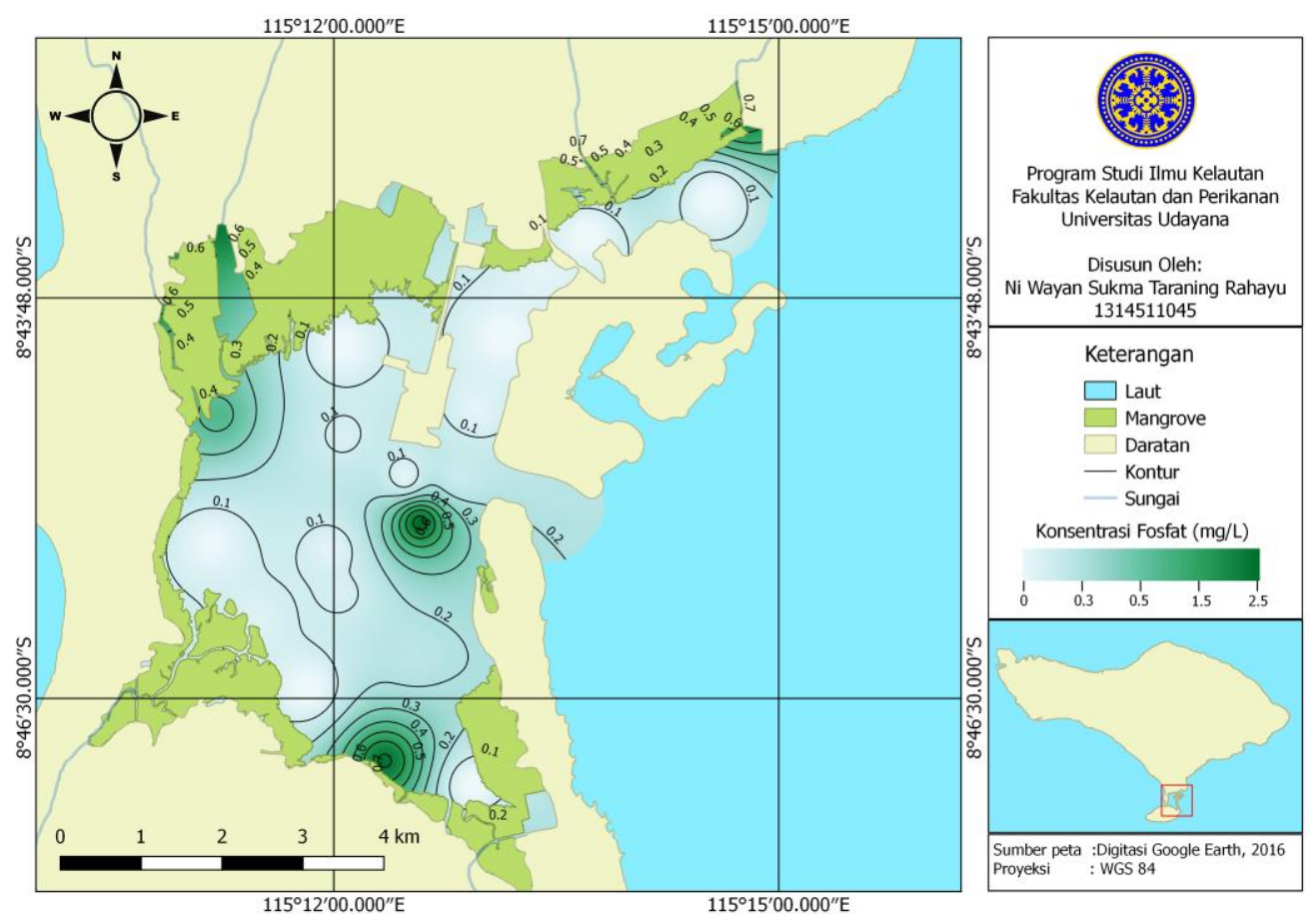

Gambar 11. Distribusi spasial fosfat di permukaan perairan Teluk Benoa bulan Februari 2017

dapat membawa sumber fosfat dari daratan. Hal tersebut mengakibatkan konsentrasi fosfat di muara sungai lebih tinggi dibandingkan daerah sekitarnya (Ulqodry et al., 2010). Konsentrasi fosfat yang rendah pada titik 14 dan 16 yang berada dekat dengan muara Sungai Bualu dan Sungai Sama diduga karena kecilnya pengaruh masukan bahan organik dari muara Sungai Sama dibandingkan dengan muara sungai lainnya sehingga konsentrasi fosfatnya menjadi rendah sedangkan pada Sungai Bualu nilai konsentrasi fosfat tidak terdeteksi. Sementara itu konsentrasi fosfat di sungai pada bulan Desember 2016 berkisar 0,203-1,200 mg/L dengan rata-rata sebesar $0,534 \mathrm{mg} / \mathrm{L}$. Konsentrasi fosfat terendah terdapat pada Sungai Sama dan tertinggi terdapat pada Sungai Buaji. Distribusi spasial konsentrasi fosfat disajikan pada Gambar 9, menunjukkan adanya nilai konsentrasi fosfat yang tinggi pada daerah muara Sungai Mati, Badung, Buaji, dan Loloan, tetapi kemudian mengalami penurunan ke bagian tengah teluk hingga timur pada mulut teluk.

Pada bulan Januari 2017 diperoleh nilai terendah sebesar $0,016 \mathrm{mg} / \mathrm{L}$ yang terdapat pada bagian tengah teluk (titik 9) dan nilai tertinggi sebesar 0,456 mg/Lyang terdapat pada bagian tengah teluk (titik 10). Tingginya konsentrasi fosfat pada titik 10 diduga karena posisinya yang terletak di dekat Sungai Sama yang mendapat pengaruh masukan dari daratan melaui Sungai
Sama, terlihat konsentrasi yang tinggi pula pada titik 16 di muara Sungai Sama. Rendahnya nilai konsentrasi fosfat pada titik 9 diduga karena terletak relatif jauh dari muara sungai sehingga pengaruh masukan dari daratan sangat kecil dan akhirnya konsentrasi fosfat menjadi rendah. Sementara itu konsentrasi fosfat di sungai memiliki nilai terendah pada Sungai Sama sebesar $0,043 \mathrm{mg} / \mathrm{L}$ dan nilai tertinggi terdapat pada Sungai Buaji sebesar 2,405 mg/L dengan rata-rata sebesar 0,681 mg/L. Gambar 10 menujukkan distribusi spasial kosentrasi fosfat pada bulan Februari 2017. Konsentrasi fosfat yang tinggi terdapat pada bagian utara dan barat teluk.

Nilai konsentrasi fosfat pada bulan Februari 2017 berkisar antara 0,016-0,739 mg/L dengan ratarata sebesar $0,198 \mathrm{mg} / \mathrm{L}$. Konsentrasi fosfat terendah terdapat pada bagian barat teluk (titik 17) dan tertinggi terdapat pada bagian tengah teluk (titik 8). Tingginya konsentrasi fosfat pada bagian tengah teluk (titik 8) diduga diakibatkan oleh pola arus yang terjadi pada kondisi pasang menuju surut, dimana terjadi perpindahan kandungan fosfat. Ardana dan Mahendra (2012) menyebutkan bahwa pada kondisi pasang menuju surut arah arus keluar menuju laut lepas. Arah arus keluar menuju laut lepas berpotensi memindahkan kandungan fosfat yang ada di muara sungai. Konsentrasi nitrat terendah pada bagian barat teluk disekitar muara sungai Badung diduga 
karena adanya bendungan pada sungai Badung yang mengakibatkan konsentrasi fosfat tersedimentasi pada daerah tersebut sehingga tidak mengalir ke perairan Teluk Benoa. Sementara itu konsentrasi fosfat di sungai berkisar antara $0,115-0,734 \mathrm{mg} / \mathrm{L}$ dengan rata-rata sebesar $0,534 \mathrm{mg} / \mathrm{L}$. Konsentrasi terendah terdapat pada Sungai Sama dan tertinggi terdapat pada Sungai Buaji (Gambar 11).

Berdasarkan nilai rata-rata konsentrasi fosfat selama tiga bulan penelitian menunjukkan nilai yang berfluktuasi dari bulan Desember 2016 hingga Februari 2017 (Gambar 12). Pada bulan Desember 2016 konsentrasi fosfat tinggi pada bagian barat teluk dan rendah pada bagian tengah teluk. Pada bulan Januari 2017 konsentrasi fosfat lebih tinggi pada bagian utara dan barat teluk dan terendah pada bagian tengah teluk. Pada bulan Februari 2017 nilai konsentrasi nitrat meningkat signifikan pada bagian selatan teluk dan terendah pada bagian utara teluk.

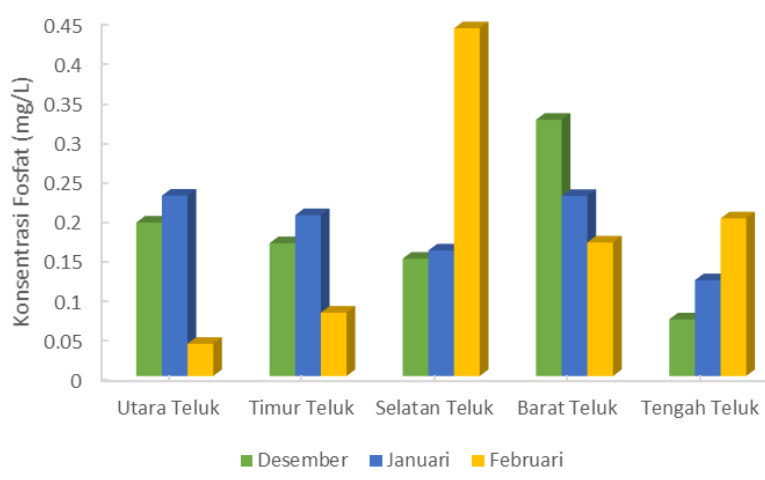

Gambar 12. Konsentrasi Fosfat bulan Desember 2016 hingga Februari 2017

Secara keseluruhan rata-rata konsentrasi fosfat selama tiga bulan penelitian cukup tinggi berkisar antara tidak terdeteksi hingga 2,405 mg/L dibandingkan dengan nilai yang diperoleh Oktaviani et al., 2015 yaitu 0,049-0,164 mg/L, maupun Karil et al., 2015 0,0046-0,9784 mg/L. Nilai yang diperoleh oleh Oktaviani et al., 2015 pada Muara Sungai Banjir Kanal Barat, Semarang maupun Karil et al., 2015 di Perairan Teluk Ujungbatu Jepara sumber pencemarannya lebih rendah dibandingkan dengan yang ada di Teluk Benoa yang memiliki 6 sungai sebagai penyumbang limbah dari daratan. Berdasarkan Pemprov Bali (2016) terkait dengan Baku Mutu Lingkungan Hidup dan Kriteria Baku Kerusakan Lingkungan Hidup, konsentrasi fosfat di semua titik pengambilan pada setiap bulannya sudah melebihi baku mutu untuk wisata bahari dan biota laut 0,015 mg/L (Gambar 13).

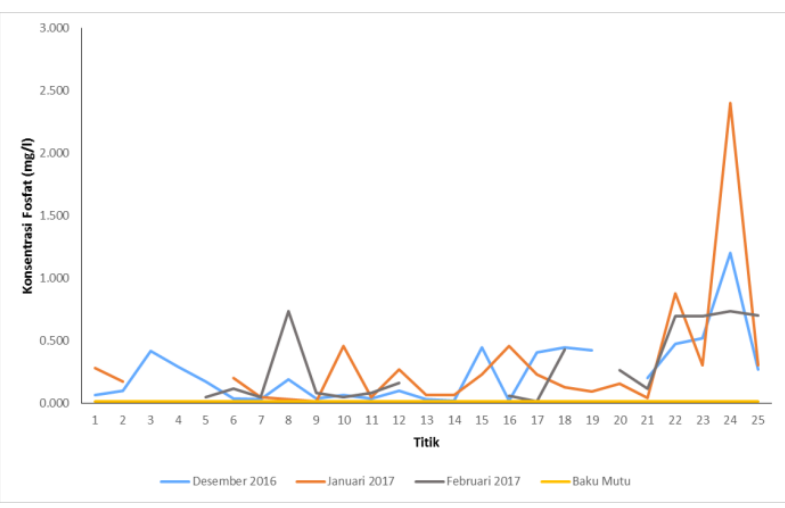

Gambar 13. Baku mutu konsentrasi fosfat

\section{Simpulan}

Konsentrasi nitrat di perairan Teluk Benoa dari bulan Desember 2016 hingga bulan Februari 2017 berkisar antara 0,036 -1,154 mg/L dan konsentrasi fosfat berkisar antara tidak terdeteksi hingga 0,739 $\mathrm{mg} / \mathrm{L}$. Konsentsrasi nitrat di sungai yg bermuara di Teluk Benoa berkisar antara tidak terdeteksi hingga 3,584 mg/L dan konsentrasi fosfat berkisar antara tidak terdeteksi hingga 2,405 mg/L. Konsentrasi nitrat dan fosfat dari bulan Desember 2016 hingga bulan Februari 2017 memiliki nilai yang fluktuatif dan rata-rata tertiggi pada bulan Februari 2017 yang diduga diakibatkan oleh kondisi curah hujan yang tinggi sehingga masukan unsur hara yang melalui aliran sungai menjadi tinggi. Persebaran konsentrasi nitrat dan fosfat cenderung lebih tinggi terdapat di sekitar muara sungai yang bermuara di Teluk Benoa. Tingginya konsentrasi tersebut diduga diakibatkanoleh masukan bahan anorganik dari daratan melalui sungai. Berdasarkan Pemprov Bali (2016) terkait dengan Baku Mutu Lingkungan Hidup dan Kriteria Baku Kerusakan Lingkungan Hidup, konsentrasi Nitrat dan Fosfat di semua titik pengambilan pada setiap bulannya sudah melebihi baku mutu.

\section{Ucapan terimakasih}

Penulis mengucapkan terima kasih kepada Badan Meteorologi dan Geofisika (BMKG) Stasiun Geofisika Klas II Sanglah Denpasar dan Stasiun Meteorologi Ngurah Rai yang telah menyediakan datacurah hujan, staf Laboratorium Komputasi, serta rekan-rekan mahasiswa Fakultas Kelautan 
dan Perikanan Universitas Udayana atas bantuannya selama penelitian.

\section{Daftar Pustaka}

Ardana, K., \& Mahendra, M. S. (2012). Study of pollutant distribution in Benoa Bay using numerical simulation and satellite data. Ecotrophic: Journal of Environmental Science, 3(2), 81-86.

Azpurua, M. A., \& Ramos, K. D. (2010). A comparison of spatial interpolation methods for estimation of average electromagnetic field magnitude. Progress In Electromagnetics Research M, 14, 135-145.

BPS Kota Depasar. (2015). Denpasar Dalam Angka (2015). Denpasar, Indonesia: Badan Pusat Statistik Kota Denpasar.

Depkes RI. (1993). Petunjuk Pemeriksaan Air Minum/ Air Bersih. (Ed ke-2). Jakarta, Indonesia: Departemen Kesehatan Republik Indonesia

Dewanti, L. P. P. (2016). Hubungan Kelimpahan dan Keanekaragaman Fitoplankton dengan Kelimpahan dan Keanekaragaman Zooplankton di Perairan Pulau Serangan. [Skripsi]. Bali, Indonesia: Program Studi Ilmu Kelautan, Fakultas Kelautan dan Perikanan, Universitas Udayana.

Dewi, N. N. D. K., Dirgayusa, I. G. N. P., \& Suteja, Y. (2017). Kandungan Nitrat dan Fosfat Sedimen serta Keterkaitannya dengan Kerapatan Mangrove di Kawasan Mertasari di Aliran Sungai TPA Suwung Denpasar, Bali. Journal of Marine and Aquatic Sciences, 3(2), 180-190.

DPPK Kota Denpasar. (2014). Survey Potensi Perikanan Budidaya dan Perikanan Tangkap di 4 Kecamatan. Denpasar. Denpasar, Indonesia: Dinas Peternakan, Perikanan dan Kelautan Kota Denpasar

Ditjen Cipta Karya PU. (2013). Profil Kabupaten/Kota: Denpasar, Bali. Jakarta, Indonesia: Direktorat Jendral Cipta Karya Kementrian Pekerjaan Umum dan Perumahan Rakyat.

Effendi, H. (2003). Telaah kualitas air, bagi pengelolaan sumber daya dan lingkungan perairan. Yogyakarta, Indonesia; Kanisius.

Faiqoh, E., Hayati, H., \& Yudiastuti, K. (2016). Studi Komunitas Makrozoobenthos di Kawasan Hutan Mangrove Pulau Penyu, Tanjung Benoa, Bali. Journal of Marine and Aquatic Sciences, 2(1), 23-28.

Hendrawan, I. G., \& Ardana, I. K. (2009). Numerical calculation of phosphate transport in Benoa Bay, Bali. International Journal of Remote Sensing and Earth Sciences (IJReSES), 6, 39-45.

Hendrawan, I. G., \& Asai, K. (2014). Numerical study on tidal currents and seawater exchange in the Benoa Bay, Bali, Indonesia. Acta Oceanologica Sinica, 33(3), 90-100.
Indra, J. (2002). Distribusi Horizontal Unsur Hara/Nutrien (N, P Dan Si) Pada Bulan Juli, Oktober, Dan Desember 2001 Di Perairan Teluk Semangka, Lampung. Desertasi. Bogor, Indonesia: Institut Pertanian Bogor (IPB).

Karang, I. W. G. (2016). Karakterisitk Pantulan Spektral Citra Landsat 8 Pada Area Pasang Surut: Studi KasusTeluk Benoa, Bali. Journal of Marine and Aquatic Sciences, 2(2), 60-66.

Karil, A. R. F., Yusuf M, \& Maskulah, L. (2015) Studi Sebaran Konsentrasi Nitrat dan Fosfat di Perairan Teluk Ujungbatu Jepara. Jurnal Oseanografi, 4(2), 386-292.

Mahendra, M. S., Suyasa, I. W. B., Nuarsa, I. W., Assyakur, A. R., Ernawati, N. M., Ardiswana, I. P. A., \& Karsika, I. M., (2015). Kajian Kualitas Perairan Tukad Badung di Kota Denpasar, Bali. [Laporan]. Denpasar, Indonesia: Program Studi Magister Ilmu Lingkungan Program Pascasarjana Universitas Udayana.

Muchtar, M. (2002). Distribusi beberapa parameter kimia di periaran muara Sungai Digul dan Arafura, Irian Jaya. Pesisir dan Pantai Indonesia, 7, 11-22.

Oktaviani, A., Yusuf, M., \& Maskulah, L. (2015). Sebaran Konsentrasi Nitrat dan Fosfat di Perairan Muara Sungai Banjir Kanal Barat, Semarang. Jurnal Oseanografi, 4(1), 85-92.

Pemprov Bali. (2016). Peraturan Gubernur Bali Nomor 16 Tahun 2016 tentang Baku Mutu Lingkungan Hidup Dan Kriteria Baku Kerusakan Lingkungan Hidup. Denpasar, Indonesia: Pemerintah Daerah Provinsi Bali.

Pramono, G. H. (2008). Akurasi metode IDW dan Kriging untuk interpolasi sebaran sedimen tersuspensi di Maros, Sulawesi Selatan. Forum Geografi, 22(2), 145-158.

Purwadi, F. S., Handoyo, G. \& Kunarso. (2016). Sebaran Horizontal Nitrat dan Ortofosfat di Perairan Muara Sungai Silungonggo Kecamatan Batangan Kabupaten Pati. Jurnal Oseanografi, 5(1), 28-39.

Rice, E. W., Baird, R. B., Eaton, A. D., \& Clesceri, L. S. (Eds.). (2012). Standard Methods for the Examination of Water and Waste Water (22nd, ed.). New York, USA: American Water Works Association/American Public Works Association/Water Environment Federation.

Risuana, I. G. S., Hendrawan, I. G., \& Suteja, Y. (2017). Distribusi Spasial Total Padatan Tersuspensi Puncak Musim Hujan Di Permukaan Perairan Teluk Benoa, Bali. Journal of Marine and Aquatic Sciences, 3(2), 223232.

Rousseau, V., Leynaert, A., Daoud, N., \& Lancelot, C. (2002). Diatom succession, silicification and silicic acid availability in Belgian coastal waters (Southern North Sea). Marine Ecology Progress Series, 236, 61-73.

Simanjuntak, M. (2012). Kualitas air laut ditinjau dari aspek zat hara, oksigen terlarut dan $\mathrm{pH}$ di perairan Banggai, Sulawesi Tengah. Jurnal Ilmu dan Teknologi Kelautan Tropis, 4(2), 290-303. 
Sudiarta, K., Hendrawan, G., Putra, K. S., \& Dewantama, I. M. D. (2013). Kajian modeling dampak perubahan fungsi teluk Benoa untuk system pendukung keputusan (Decision Support System) dalam jejaring KKP Bali. Denpasar, Indonesia: Conservation International Indonesia (CII) Bali.

Sugiyono. (2012). Metode Penelitian Kuantitatif, Kualitatif, dan RED. Bandung., Indonesia: Alfabeta.

Suteja, Y. (2016). Beban Pencemar Dan Kapasitas Asimilasi Amonium dan Nitrat Saat Pucak Musim Barat di Teluk Jakarta. Journal of Marine and Aquatic Sciences, 2(1), 16-22.
Tuahatu, J. W., \& Tubalawony, S. (2008). Sebaran Nitrat dan Fosfat Pada Massa Air Permukaan Selama Bulan Mei 2008 di Teluk Ambon Bagian Dalam. Jurnal Manajemen Sumberdaya Perairan, 5(1), 34-40.

Ulqodry, T. Z., Yulisman, Y., Syahdan, M., \& Santoso, S. (2010). Karakterisitik dan Sebaran Nitrat, Fosfat, dan Oksigen Terlarut di Perairan Karimunjawa Jawa Tengah. Jurnal Penelitian Sains, 13(1), 13109-35-1310941

Wiyanto, D. B., \& Faiqoh, E. (2015). Analisis vegetasi dan struktur komunitas Mangrove Di Teluk Benoa, Bali. Journal of Marine and Aquatic Sciences, 1(1), 1-7.

(C) 2017 by the authors; licensee Udayana University, Indonesia. This article is an open access article distributed under the terms and conditions of the Creative Commons Attribution license (http://creativecommons.org/licenses/by/3.0/). 